\title{
Role of Marketing Function in the Rubber Marketing Societies for the Benefit of Small Rubber Growers
}

\author{
Sunil Varghese \\ Marthoma College of Management and Technology, Ernakulam, India
}

\begin{abstract}
The establishment of Rubber marketing co-operative marketing societies was the initiative of Govt. of Kerala in order to provide fair price and to bring the small growers from the unorganized segment to organized segment. The primary objective was to provide an efficient market system for helping the farmers for getting accessibility toward the market. However, the efforts of the government to improve the marketing system of rubber marketing have been only partially successful. Moreover, the progress of regulated markets is not uniform in all areas. The main objectives of a co-operative marketing society are to make arrangements for the sale of agricultural produce of its members and to work as marketing supporting organization. Hence in this article, emphasize is given on the marketing function for providing the needs of small rubber growers.
\end{abstract}

Keywords: Cooperative, Marketing, Value addition, small rubber growers

\section{Introduction}

According to the Reserve Bank of India, "a co-operative marketing society is an association of cultivators formed primarily for the purpose of helping the members to market their produce more profitably than possible through the private trade." In general it is a process of marketing of products which enables the growers to market their produce at better prices, followed by the intention of securing better marketing services and ultimately contributing to improvement in the standard of living of members.

\section{Review of Literature}

Going back to the history of marketing for the last 10 years it is perceived as set of values and processes rather than marketing as a function. In this view, marketing becomes everybody's job, which potentially diffuses the marketing function's role but increases marketing's influence (Greyser 1997). As McKenna (1991, p. 68) notes, "Marketing is everything and everything is marketing," or as Haeckel (1997, p. ix) states, "Marketing's future is not a function of business, but is the function of business." The empirical literature on market orientation is the most profound indication of this change in perspective. Although it has been defined in a variety of ways, several empirical studies of business organizations indicate that an organization wide market orientation has a positive impact on the financial performance of firms and their new products (Day and Nedungadi 1994; Deshpandé, Farley, and Webster1993; Jaworski and Kohli 1993; Kohli, Jaworski, and Kumar1993; Moorman 1995; Narver and Slater 1990). To make our case, we present a framework that defines the scope of the marketing function and how it operates in the crossfunctional world of cooperative marketing societies. At the heart of this framework is the idea that the marketing function facilitates the link between the small rubber growers, president role and marketing function within the firm (Day 1994). Hence we should give more thrust on the marketing function which includes the aspects like transportation, grading, fair price, accessibility. Working from the assumption that the marketing function is having a broader perspective on the functioning of variables that contributes to firm performance beyond, the critical question is then how to blue print the marketing function so as to provide the greatest value for organizations. In this section, we develop a framework that defines the scope of the marketing function. At the heart of this framework is the idea that the marketing function's key contribution is to serve as a link between the small rubber grower and various processes within the firm (Day 1994). Therefore, we expect that, as the marketing function develops knowledge and skills related to each of these connections, the perceived value of the function within the organization will increase. To clarify terms, we define the value of the marketing function within the rubber marketing societies as the degree to which it is perceived to contribute to the success of the firm relative to other functions.

The question is to reframe the structure of the organization in order to maximize the efficiency of the functioning of marketing.Within this broad topic, the specific question we address pertains to the proper organization of marketing in firms. Two specific structures that currently are being scrutinized by practitioners and that offer distinctive theoretical approaches for scholars are examined here: a functional marketing organization and a process marketing organization. A functional marketing organization refers to the concentration of the responsibility for marketing activities (knowledge and skills) within a group of specialists in the organization. The benefits of functional structures are well documented and include enhanced efficiency and ability to develop specialized, distinctive capabilities (e.g., Thompson and Strickland 1983). The risks include the challenge of coordination between specialized functions; interfunctional conflict, functional myopia, and overspecialization.

A marketing process organization refers to the dispersion of marketing activities (knowledge and skills) across nonspecialists in the organization (Workman, Homburg, and Gruner 1998). This approach can take a variety of forms. For example, Kohli and Jaworski (1990, p. 3) define market

\section{Volume 4 Issue 12, December 2015}




\section{International Journal of Science and Research (IJSR) \\ ISSN (Online): 2319-7064 \\ Index Copernicus Value (2013): 6.14 | Impact Factor (2014): 5.611}

orientation as the organization wide generation, dissemination, and responsiveness to market intelligence.

A precept of the marketing concept contends that business achieves success by determining and satisfying the needs, wants, and aspirations in the input and output marketing. Few would argue that this determination and satisfaction of target market wants and needs is critical for firm success. These concepts, traditionally thought to be part of the marketing function of the firm, have fueled scholars' interest in the role of marketing within the firm (e.g., Becherer et al., 2003; Berthon et al., 2008; Moorman and Rust, 1999; Simpson and Taylor, 2002; Webster, 1981, 1992, 2003; Webster et al., 2003).Marketers use numerous tools to elicit the desired responses from their target markets. These tools constitute a marketing mix. Marketing mix (transportation, grading, fair price, accessibility) is the set of marketing tools that the firm uses to pursue its marketing objectives in the target market

\section{Conceptual Model}

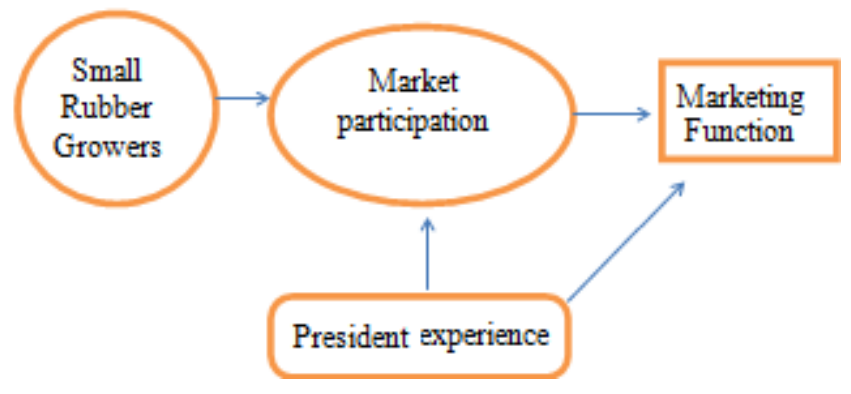

\section{Participation}

FAO, (1991), People's participation implies the active involvement in development of the rural people, particularly disadvantaged groups that form the mass of the rural population. Participation should be viewed as an active process in which people take initiatives and action that stimulated by their own thinking and deliberation and which they can effectively influence.

\section{President experience}

As Stevenson and Gumpert (1985) noted, firms with an entrepreneurial focus tend to be flat organizations with informal networks of employees and functions. Presidential experience can improve the participation of the members and in return their will be more emphasis on the marketing function. Entrepreneurial organizations typically have an evolving management structure and are more abstract in defining the roles of management (Freeman and Engle, 2007). Firms with anon-entrepreneurial focus are termed administratively oriented and are organizations with clearly defined authority and structure. It is reasonable to infer from Stevenson and Gumpert's work that firms with an administrative focus will have more clearly delineated functions/departments such as marketing. If the marketing function is more clearly defined, we would expect marketing to have greater influence.

\section{Background of President}

The top managers influence and shape the firm's direction and focus. Within SMEs, thet op manager's role is pivotal for growth and expansion (Hutchinson et al., 2006). For smaller firms, this would seem even more relevant where all employees are likely to feel the CEO's influence. The psychologist Duncker(1945) first coined this phenomenon "functional fixity" to refer to the observation that people tend to reactto an object in terms of its usually defined function. That is, a hammer is used to drive nails but is not frequently used as a paperweight, although obviously it could be. Business researchers have applied this idea to management and have found that managers are also influenced by their previous training and find it difficult to deviate from their functional training when devising a solution to a problem. For example, engineers seek technical solutions, accounting managers seek financial solutions, and marketing managers look to advertising and promotion to solve problems (Ashton,1976; Barnes and Webb, 1986; Chang and Birnberg, 1977)

\section{Marketing function}

The role of marketing function depends upon the intensity of member's participation and the leadership quality shown by the president. In cooperative marketing gives more emphasis on the members participation as it organized and run by the members of the cooperative society. Here the input and output marketing is basically related to the marketing function and the presidential experience. Thus, the marketing department that assumes this management function should be deemed important and influential. Homburg et al.'s (1999) study showed the marketing function to be a significant influence in large firms. This suggests that marketing, as function and influence in business, is not as well developed for has a way to go before it enjoys the same influence found in larger firms.

\section{Conclusions}

On the basis of an extensive study, we draw the following conclusions:

1) In cooperative Marketing organization there must be harmonious coordination between the members and the organization leader. The primary coordination may be viewed as the effective input and output marketing.

2) The extent to which the marketing function manages depends upon the market participation and this connection contributes to financial performance.

3) The president approach should improve the participation of the members and should give more thrust on democratic leadership so as to improve the functioning of the entire organization.

\section{References}

[1] Association of Marketing Functions and Mercantile Organization Author(s): L. D. H. Weld Source: The American Economic Review,Vol. 7, No. 2 (Jun., 1917), pp. 306-318.

[2] Prakash Nedungadi (1994), "Managerial Representations of Competitive Advantage," Journal of Marketing, 58(April), 31-44.

[3] Greyser, Stephen A. (1997), "Janus and Marketing: The Past, Present and Prospective Future of Marketing," in Reflections on the Futures of Marketing, Donald R. 


\section{International Journal of Science and Research (IJSR) \\ ISSN (Online): 2319-7064}

Index Copernicus Value (2013): 6.14 | Impact Factor (2014): 5.611

Lehmann and Katherine Jocz, eds. Cambridge, MA: Marketing Science Institute, 3-14.

[4] Kohli, Ajay K. and Bernard J. Jaworski (1990), "Market Orientation: The Construct, Research Propositions, and Managerial Implications," Journal of Marketing, 54 (April), 1-18.

[5] Lehmann, Donald R. (1997), "Some Thoughts on the Future of Marketing," in Reflections on the Futures of Marketing, DonaldR. Lehmann and Katherine Jocz, eds. Cambridge, MA: Marketing Science Institute, 121-36.

[6] McKenna, Regis (1991), "Marketing Is Everything," Harvard Business Review, 69 (January/February), 6579.

[7] Moorman, Christine (1995), “Organizational Market Information Processes: Cultural Antecedents and New Product Outcomes.

[8] Rust, Roland T., Anthony J. Zahorik, and Timothy L. Keiningham (1995), "Return on Quality (ROQ): Making Service Quality Financially Accountable," Journal of Marketing, 59 (April),58-7

[9] Srivastava, Rajendra K., Tasadduq A. Shervani, and Liam Fahey (1998), "Market-Based Assets and Shareholder Value: AFramework for Analysis," Journal of Marketing, 62 (January), 2-18.

[10] Homburg, C., Workman, J.P. and Krohmer, H. (1999), "Marketing's influence within the firm", Journal of Marketing, Vol. 63 No. 2, pp. 1-17.

[11] Moorman, C. and Rust, R.T. (1999), "The role of marketing", Journal of Marketing, Vol. 63.

[12] Dholakia, R.R. and Kshetri, N. (2004), "Factors impacting the adoption of the internet among SMEs", Small Business Economics, Vol. 23 No. 4, pp. 311-22.

[13] Sorensen, J.B. (2007), "Bureaucracy and entrepreneurship: workplace effects entrepreneurialentry", Administrative Science Quarterly, Vol. 52 No. 3.

[14] Hutchinson, K., Quinn, B. and Alexander, N. (2006), "The role of management characteristics in the internationalization of SMEs: evidence from the UK", Journal of Small Business and Enterprise Development, Vol. 13 No. 4, pp. 513-34.

[15] Duncker, K. (1945), “On problem solving, (translated by L.S. Lees)”, Psychological Monographs, Vol. 58

[16] Ashton, R.H. (1976), "Cognitive changes induced by accounting changes: experimental evidence on the functional fixation hypothesis", Journal of Accounting Research, Vol. 14 No. 3.

[17] Becherer, R.C., Halstead, D. and Haynes, P. (2003), "Marketing orientation in SMEs: effects of the internal environment", New England Journal of Management, Vol. 3 No. 1, pp. 1-17.

[18] Bennett, R.J. and Smith, C. (2002), "Competitive conditions, competitive advantage and thelocation of SMEs", Journal of Small Business and Enterprise Development, Vol. 9 No. 1,pp. 73-86.

[19]Berthon, P., Ewing, M.T. and Napoli, J. (2008), "Brand management in small to medium size enterprises", Journal of Small Business Management, Vol. 46 No. 1, pp. 27-45.

[20] DiMaggio, P.J. and Powell, W.W. (1983), "The iron cage revisited: institutional isomorphism and collective rationality in organizational fields", American Sociological Review, Vol. 48 No. 2, p147-60.
[21]Meyer, J.W. and Rowan, B. (1977), "Institutional organizations: formal structures as myth and ceremony", American Journal of Sociology, Vol. 82 No. 2, pp. 34063.

[22] Simpson, M. and Taylor, N. (2002), "The role and relevance of marketing in SMEs: towards a new model", Journal of Small Business and Enterprise Development, Vol. 9 No. 4, pp. 370-82.

[23] Simpson, M., Padmore, J., Taylor, N. and Frecknall, J. (2006), "Marketing in small and medium sized enterprises", International Journal of Entrepreneurial Behaviour \& Research, Vol. 1No. 6, pp. 361-87.

[24]24. Day, George S. (1990), Market-Driven Strategy. New York: The Free Press (1994), "The Capabilities of Market-Driven Organizations, Journal of Marketing, 58 (October), 37-52.

\section{Author Profile}

Sunil Varghese is an Assistant Professor in the Economics, Marketing, and Service Marketing at Marthoma College of Management and Technology (MCMAT).His areas of research combines Cooperative Marketing and its economic relevance, in the farming community of Kerala using field experiments to test insights of economic implications in the context of global changes in India. He also conducts research on questions of Service Marketing and related areas of Retail sector. 